\title{
Examining the Impact of China-Africa Educational Cooperation: A Case study of Cameroon
}

\author{
Emmanuel Chidiebere Edeh Tachago Tchuente Ines Brenda \\ College Of International Education And Culture, Zhejiang Normal University, PR.China
}

\begin{abstract}
Educational co-operation within the China-Africa Relation has been identified as an important sector on which Africa can leverage to boost its education and skill development that have been some of the bottlenecks of Africa's development. This cooperation centers on China's role in Africa's human resource development through soft power with Africa and promoting skill development for African countries. As such, the paper examined the different dimensions of China-Africa educational cooperation and its impact with a focus on Cameroon, through a review of corresponding literature which include; published and unpublished papers, journal papers, government reports and newspapers articles. The study found that there still exits huge skill gap with no formal evaluations, even though there have been records of skill development schemes as well as increase in pledges made with each successive high level summits. Finally, the study maintains that strong internal policies and pragmatic action on Cameroonian side will enable Cameroon to properly engage China for WIN -WIN cooperation.
\end{abstract}

Keywords: China; Cameroon; Educational cooperation; skill development

DOI: $10.7176 / \mathrm{JEP} / 10-34-03$

Publication date: December $31^{\text {st }} 2019$

\section{Introduction}

In recent years, the world has witnessed a strong presence of China in Africa. The continuous growth, change and overall development of China-African cooperation is evident in political, economic and educational fields. Educational cooperation between Africa and China dates back to the precolonial period of 1950s. China established official bilateral trade agreement with African countries (Egypt, Morocco, Algeria, Guinea, Sudan and Somalia) at the time, as they broke free from colonial shackles down to the millennium era with the inception of the Forum on China-Africa Cooperation in 2000 (FOCAC). This forum gave a new impetus to educational exchanges under its wings. It first started as a ministerial meeting (FOCAC) held in Beijing 2000, and From 2006, metamorphosed into a high-level outstanding summit for China-African co-operation, which take turns in China and Africa tri-annually. Education cooperation between china and Africa is theoretically based on mutual support and recognition of the complementarity in pace of development between the two partners. Ketema and Hong (2009) asserted that their cooperation has also been a reflection of the principle of South-South Cooperation in terms of the exchange of resources, technology, and knowledge between developing countries also known as countries of the global South. Which Gillespie (2006) referred to as the flow of international students among Third World nations themselves.

By 2013, China has also become a major destination for international students, and ranks third overall among the world (Sheehy 2013) with International students enrolled in over 1004 higher education institutions in China (China education center 2019). In 2015, there were over 397,635 foreign students from 202 countries and regions studying in China showing a 5.46\% increase from the previous year of about 377,054 and about $12.52 \%$ constituting 49,792 are from Africa(Statistics of Foreign Students in China 2016). Victoria and Nathan (2017), reported that by 2014, China surpassed the US and UK to become the second most popular destination for African students studying abroad. The influx of foreign students to China in the recent time has been linked to the Belt and Road Initiative, and FOCAC framework on the African side. More so , China have continued to forge its Cooperation with African countries in all areas including--trade, commerce, economic, political, health, cultural and education (Brautigam 2009; Nordtveit 2011; King, 2010, 2013, 2014;) and China's assistance towards education development is a priority for Africa's development. As stated in the fourth FOCAC forum, The Chinese government's official resolution on training and educational assistance emphasizes that better education is the basis of, and holds the key to, social stability and economic development. Following Ketema and Hong (2009) observations, African countries prefer South-South Cooperation to the north because of some factors. For instance, In the case of South-South Cooperation costs of education are much less than in the North; it reduces brain drain and isolation of scientists in the South; enhances ability of scientists to work in Third World environment and address real-life problems; facilitates building long-term links between institutions of learning and research in the South. This also underscores the growing strength in China-Africa cooperation.

Nevertheless, Within the China African cooperation, a sizable chunk of literature on China's human resource development assistance to Africa (Li 2006; He 2007; King 2009, 2013, 2014; Nordtveit 2011; Shao 2012; Ehizuelen 2018) and the assessment of socio- cultural life and experiences of African trainees in China 
(Ismail and yang 2003; Dong and Chapman 2008; King 2010; Jian 2015) have focused more on the philosophical and contextual background. However, little focus have been placed on assessment of broader impacts of education and skill development towards individual trainees and their home countries, (Yuan 2013; Makundi et al. 2017). Evaluation models involving broad range of methodological approaches like Kirkpatrick (1975) and CSCUK (2014), could be adopted by non-traditional donors like China to access the impact of its overseas education programs. The selection of any of these evaluation models depends on the approaches that the donor desires to employ. Makundi et al. (2017), pointed out some of the limitations of CSCUK model. For instance, difficulty of selecting relevant control group; lack of in-depth contextual data in most experimental designs; high research cost and ethical considerations. While Perna et al. (2014) noted the limitation of Kirkpatrick model as oversimplifying the benefits of training through the over-focus on the trainees' employers contrary to interaction with the wider surrounding society. China on the other hand, either do not have or rarely employ any of the above mentioned evaluation models, and access to such data is limited. As such, the present study adopted the qualitative educational approach of, using context analysis, exploratory literature review, and qualitative descriptive case study designs (Bogdan \& Biklen 2003). Ryan and Bernard (2002) regard this approach useful as it allows authors to immerse in the secondary data derived from various literature sources, and to analyze the phenomenon in depth for a better understanding of the general context, and identification of major themes. The study examined the impact of China-Africa Educational cooperation in Africa with a focus on Cameroon, through the different dimensions of China's education and training cooperation with Africa which includes: support to short term and long term training of Cameroonians in China; university to university cooperation between China and Cameroon; development of Confucius Institutes; development of education or training projects and project-related training within Cameroon. It beams its light from the past decade since the establishment of FOCAC, and seeks to answer the following research questions:

1. What role have the China Cameroon cooperation in education played to wards improving education and skill development in Cameroon?

2. To what extent have the training and skill development program in Cameroon impacted on bridging the skill gap and promoting independent innovations in Cameroon?

Through a review of corresponding literature and materials the present study seeks to provide suggestions towards improving the education and skill development within the Sino-Cameroon educational cooperation.

\section{Background Literature on Sino-African Educational Cooperation}

Sino- African Educational exchanges began in the 50s with Egypt and by the end of 1966 about 164 African students from 14 African countries had studied in China, and 14 Chinese teachers had worked in Africa (He 2007; Jian 2015). This exchanges ended abruptly due to cultural revolution of May 1966-1972. However, by 1978, 43 African countries had established diplomatic relations with China ( $\mathrm{Li} 2007$ ) and by the 1980s the number of African students coming to study in China began increasing (Edeh \& Wang, 2018). Omoruyi et al. (2017) noted that China's increased economic engagement with Africa countries in the last decade has resulted in the rapid increase of educational cooperation, especially through the Forum On China And Africa Cooperation (FOCAC). During the first FOCAC forum, China and Africa agreed to establish the "African Human Resources Development Fund" through which China can financially support Africa's personnel training and educational development - provision of African students with Chinese government scholarships; helping African countries construct laboratories and schools; and sending teachers and volunteers to Africa to assist with Chinese language teaching (Jian 2015). By 2013, China had provided over 45,000 training for Africans, covering more than 20 fields including economics, science and technology, and environmental protection (Hu 2013).

The first Sino-African Education ministerial meetings held in Beijing in 2005 was marked with the signing of the -Beijing Declaration by 17 African countries (Omoruyi et al. 2017). As observed by Nordtveit (2009) the declaration was geared towards a common commitment towards educational development with special focuses on primary education, vocational and technical education. Furthermore, the 2005 FOCAC declaration recognized the importance of education to economic development--as evident in the process of pursuing economic development, mutual benefit, poverty alleviation and the intention to pursue multilateral consultations around common issues. As such, during the FOCAC summit of 2006, the Chinese government listed four main area of education cooperation with Africa, which includes- : (1) setting up rural schools in Africa, (2) increasing the number of Chinese Government Scholarships, (3) providing training for professionals and educationalists of various institutions in Africa, and (4) the establishment of Confucius Institutes (CI) for Chinese language teaching and the encouragement of teaching African languages in Chinese universities (Edeh \& Wang 2018). More so, in 2011, a total of 44 presidents and vice chancellors from Chinese and African universities met in Paris for the UNESCO China-Africa University Leaders summit to discuss how to advance university cooperation between these two parties (Omoruyi et al. 2017; Edeh \& Wang 2018). following this summit in 2012 during the FOCAC meeting, China announced its three years - African Talents Plan which sets to train 30,000 Africans, award 18, 000 government scholarships and to build cultural and vocational training facilities by 2015 
(Sino graduate 2012) in (Omoruyi et al. 2017). Hanauer and Morris (2014) in (Omoruyi et al. 2017) noted that there was an increase in 2012 FOCAC pledge compared to the 2009 FOCAC meeting which foresaw 5, 500 government scholarship and promised to train 20,000 Africans. This also witnessed a further increase in 2015 FOCAC summit held in Johannesburg where China also pledged to enhance development experiences by offering occupational training courses for African youths and training young talent in agricultural science, increasing the Chinese government scholarships from 30, 000 in 2015 to 50,000 in 2018 for Africa and invite 2,000 young people from Africa to visit China (Johannesburg action plan 2015). China through the FOCAC framework is forging its overall relations with African countries and has remained hesitant about using the traditional donor's modality (China's Foreign Aid 'White Paper' 2011) .

Since the inception of FOCAC in the year 2000, China's aid and cooperation policies with African countries largely follows strategically the 3 year plan of the FOCAC framework and often a consensus on most of the aid and cooperation projects are reached between China and African countries during the high-level meetings. For instance, As stated by Chinese embassy in Yaounde" We are trying to make a strategic plan, a long-term plan. Every third year, the inter-ministerial forum [FOCAC] evaluates the actions and makes plans for new actions. For example, we decided to construct schools. In the years to come, we will evaluate whether we should continue to give support in the same sector. These decisions are taken during the meetings of the forum. The principles of the cooperation are said to be related to African needs, and secondly, to help in domains that the Chinese are capable of help them in; hence the focus on practical aid projects, rather than the use of conditionality and a meta narrative on, for example, structural adjustment or economic policies, human rights, the environment, or other themes that are often being promoted by the Western donors." (Omoruyi et al. 2017). King (2014) pointed out that FOCAC pledges are not bilateral but pan-African, and are largely executed by Chinese expertise, this includes: Chinese universities or vocational colleges, Chinese think tanks, scientists, agricultural technologists or language teachers, and medical personnel. However, King (2010) asserted that there is also still the strong bilateralism that underlines the importance of understanding the way China has chosen to work with any particular country. Zheng (2016) also noted that China, like the established donors also justifies its overseas economic activities with development objectives. but such development objectives have often been subordinated to strategic, diplomatic, or commercial considerations, while maintaining that it helps developing countries, (especially African countries) to promote sustainable economic development and poverty reduction.

There are 3 major perspectives of China's development cooperation strategy. The first perspective is the Beijing's desire to secure strategic resources - those most fundamental to national security - and secondarily for diplomatic reasons. The second perspective is the Chinese aid policy which has always maintained its distance from the established aid model under the guidance of the OECD Development assistance Committee (DAC) and will not necessarily challenge the existing international aid regime. The third perspective argues that China does not have a coherent aid strategy that is carefully designed and implemented (Zheng 2016). Diplomatic and commercial agendas often drives the Chinese aid policy as observed by some scholars. The diplomatic agenda regards aid as an instrument for Exercising diplomatic influence on the international stage and deepening cooperation with selected countries whereas the commercial agenda views aid as a useful way of assisting domestic businesses to go international and expand exports and investments (Lum et al. 2009; Brautigam 2009; Varrall 2015). More so, the Chinese aid and cooperation administration in policy of non-interference and in its principles of non-conditionality, may have even less control than other donors over the recipient country (Sun 2014: p20). for instance, the use of funding and the selection of personnel to be trained or for scholarship awards. For this reason, China have been heavily criticized for fostering corruption in Africa by some school of thoughts (Freschi 2010; Clinton 2011), however, others view China's approach as balanced- development (Tull 2006; Fantu \& Cyril 2010) approach. China also have maintained that it follows the dictates of the United Nations on the respect of sovereignty and non-interference as evident in China-Africa policy (PRC 2006).

Nevertheless, studies has shown that China had only recently emerged as a donor (king 2009; Nordtveit 2011), and the Chinese institutions have not yet had time to adjust to the dramatic increase in aid and cooperation that took place after the inception of FOCAC. As cited in Omoruyi et al. (2017) Chinese Embassy Personnel in Yaounde stated - Our statistic services are not very good, and we are yet not established a very good data system.... Chinese aid and cooperation with Africa have been hindered by a lack of transparency, and a lot of the documentation on prior projects has been lost. The new strategy of aid to foreign countries is important for us, and we are currently reviewing old projects and practices, to learn for the future. Edeh and Wang (2018) also noted that funding, Scholarships and training are often in line with the FOCAC agenda and will involve staff in many Chinese and African ministries such as (Ministries of Commerce, Foreign Affairs, Culture, Education, Science \& Technology, Agriculture, and Medicine etc.), host universities in China, as well as both the political, economic \& commercial branches of all of China's African embassies.

Furthermore, with increase in scholarship awards in the areas of human resource training in the recent years by donor countries like Germany, UK, Australia and China (Cuthbert et al. 2008; Woodfifield 2009; King 2013) studies (Baker et al. 1996; Makundi et al. 2017) have suggested the importance of published evaluation data in 
the area of educational cooperation by the emerging donors and non-OECD donors, including China and India. UNESCO (2015) report also highlighted the importance of evaluation in the area of education cooperation while asserting that often scholarships are used as a means to see aid allocations return to the donor country' as there is little evidence that scholarships build knowledge and teaching capacity within beneficiary countries. To this end, this paper agrees with Makundi et al. (2017) that case-by-case variations in trade-offs between benefits and shortcomings towards the recipient economies justifies the importance of regular evaluation studies. As such studies will assist in improving accountability and facilitate access to data and information from these donors as well as improve the understanding of overall impact in educational cooperation globally.

\section{Education and skill development in Sino-Cameroon Education Cooperation}

Since 1971 when the Republic of Cameroon established relations with the People's Republic of China, Its been over four(4) decades of strategic partnership and successive visits of officials from the both sides which has led to deepening of cooperation between Cameroon and China. With a population of about 25million people whose labour force constitute about $65 \%$ of the total population, the country's population is estimated to reach about $37,722,498$ million by 2035 (World population review 2019). Although there is positive increase in population, however, $40 \%$ of the population is estimated living below the poverty level and poor access to proper education especially in the rural areas. Also lack of employable skills have been a bottle neck for the teeming population of the youths in Cameroon to secure well paid jobs resulting to high unemployment rate. Nevertheless, in seeking a better alternative towards solving its developmental issues, Cameroon have turned towards China as a reliable partner other than the traditional donor (France). Backed by strong political will, the republic of Cameroon have forged its strong relation with China on mutual economic needs and interests. While China needs Cameroon's natural resources and raw materials (oil, cotton, timber and iron), Cameroon needs the China's rapidly built and easily financed infrastructure (Cabestan 2015). the mutual interest and benefit that Sino-Cameroonian cooperation pursues is evident in the speech made the former Chinese President, Hu Jintao during an official visit to Cameroon in January 2007, that China's relation with Cameroon is sincere, based upon equality, reciprocal benefits and win - win cooperation (Omoruyi et al. 2017).

Over the decade, Bilateral cooperation between China and Cameroon have significantly increased, A 2017, report from the presidency of the Republic of Cameroon stated that, In 2015, China was Cameroon's first trade partner, while the latter was the second largest beneficiary of Chinese aid in Africa; FCFA 1,430 billion. Chinese companies are involved in 70\% of Cameroon's official 'structuring projects', which are the key development and particularly infrastructure projects(Dams, hydroelectric power plant, low income-house construction, high-way construction, deep water port among others) launched since the end of the 2000s (Cabestan 2015; Atabong 2018). The diplomatic cooperation also covers other areas such as aid towards health, culture and tourism exchanges, military training, and educational exchanges. However, We shall focus on the Sino-Cameroonian education cooperation for better understanding and to proffer answers to the following research questions-

1. What role have the China Cameroon cooperation in education played to wards improving education and skill development in Cameroon?

2. to what extent have the training and skill development program in Cameroon impacted on bridging the skill gap and promoting independent innovations in Cameroon?

Its impact in tackling the problem of skill deficit through these main axis of educational cooperation: support to short term and long term training of Cameroonians in China; university to university cooperation between China and Cameroon; development of Confucius Institutes; development of education or training projects in Cameroon.

\subsection{Support To Short Term And Long Term Training Of Cameroonians In China}

Human resource development and capacity building have been a major bottle neck that African nations have to face towards achieving "the Africa we want"(Agenda 2063) of which Cameroon a developing country is not left out. Outlined in Cameroon's vision 2035 report 2009, is the desire to develop its industries, substantially increase exports, provide import substitution, and open local markets to foreign investments, as well as the strong desire to attaining the level of middle-income economies. Also the Cameroon development strategy is deep-seated in the country's National Growth and Employment Strategy Paper (GESP) with a reference framework for government action over the period 2010 - 2020. It replaced the Poverty Reduction Strategy Paper (PRSP) instituted in 2008 (which was simply a tool aimed to help guide the attainment of the MDGs goals) following its non-satisfactory outcomes (Omoruyi et al. 2017). China, on the other hand, has responded positively to make skills transfer a key element of a new phase in its partnership with Africa countries, as Beijing agreed to support Africa in vocational/technical training, higher education and science and technology (Ehizuelen 2018). The Johannesburg action plan (FOCAC) 2015, emphasized heavily on the need to encourage education and skill transfer within the framework. As cited from Ehizuelen (2018) China and Africa attached importance to skills transfer, and to carrying out exchanges in technological innovation policies and the building 
of science and technology parks and to encouraging research institutions and enterprises to have intensive cooperation covering areas such as agriculture, industry, civil aviation, energy, and resource, tax, logistics.

As part of china's soft power diplomacy towards Africa, China provides Cameroon technical training for a much shorter period of time (2-3 weeks), and a longer period of 3 - 4 months with a programme specially designed for civil servants and politicians (numbering between 100 and 110 yearly) who travel around China free of charge(Cabestan 2015). Nordtveit (2011) stated that, In 2008, approximately 60 Cameroonian civil servants and 30 technicians were trained. More so, the Chinese telecom giant Huawei has been active in bring digital and telecommunication revolution to the ICT sector in Cameroon.. According to Atabong (2018) in May 2018, Huawei Marine, partnering with China Unicom and Cameroon Telecommunications (Camtel) began laying the $6,000 \mathrm{~km}$-long South Atlantic Inter Link (SAIL) cable system from Kribi in Cameroon to Fortaleza in Brazil. South Atlantic Inter Link(SAIL) is said to be the first cable system to directly connect Africa and South America is modelled using Huawei Marine's advanced $100 \mathrm{G}$ technology and will have a capacity of 32Tbits/s once completed. He further reiterated that, In the last eight years, Chinese mobile phone manufacturers like (Techno Mobile, Huawei, Itel, LG, ZTE, Oppo, OnePlus) and a myriad of others (mobile broadband modems) have been overwhelming the Cameroonian market with affordable smart phones, giving thousands of people the incentive to go online and easiness to sign up to multiple telecom services. More so, Sichuan Telecommunications Construction Engineering Company has also been tasked to construct, equip and commission nine university digital development centers to facilitate e-learning and e-administration. Nevertheless, Besides connecting people together, the chinese electronic gadgets in the Cameroonian market have also provide opportunity for unemployed youths who either engaged in repairs or sales of this gadgets.

However, missed reactions has been raised concerning China's engagement in Cameroon's Information and communication technology (ICT) sector. For instance commentators in Atabong (2018) like Achia Rolence, a computer engineer and an alumnus of the University of Buea, praised china for the role its in Cameroon's digital sphere, he disclosed that the Chinese company Huawei has a program with the university whereby students go to China for intensive training in IT, However, he asserted that China has not provided any direct assistance to help their emerging tech ecosystem - Silicon Mountain - in Buea. Also Bama Etienne Cham, an expert in international trade negotiations, holds the that China is facilitating Cameroon's digital boom but questions the cost. "Looking at its sustainability, there is a need to be cautious about the quality and other impacts of these products [IT devices]. Such trading approach where all, including services, comes from China without transfer of technology is a serious call for concern. How do we sustain when we don't have the know-how? " he stated. This however questioned the fact about skill transfer in Sino-Cameroonian education Cooperation, and the need for impact assessment studies (Kaufman et al. 1996; Tamkin et al. 2002). As proposed by Kirkpatrick (1975) using the four-level training evaluation approach designed to assess the trainees' perspectives on the training courses they attended, by using the four levels of training outcomes namely; reaction, learning, behavior, and results.

\subsection{Scholarship}

As part of the long term training for Africans in China, Scholarships are awarded in different disciplines to African students of which Cameroonian students also benefit. Like most African countries, Cameroon relies on foreign aid to tackle many problems especially in the areas of educational development and skill transfer. As such China's long term training of Cameroonians through different scholarship programs are aimed at assisting Cameroon to build up the necessary skills required to brace up the human resource capital for the $21^{\text {ist }}$ century industries. In a statement issued by Mr An Yan, Director of the Division for Student Mobility in the Chinese Ministry of Education, stated that 718 Cameroonians have received Chinese scholarships training since 1959. Since the past decade especially with the commencement of the high level FOCAC framework, scholarships quotas for African students in China have increased successively. for Cameroon, in 2009, scholarship quota was increased to 40 places making China emerge the first scholarship donor, ahead of Morocco and Algeria (Nordtveit 2011). In 2016 more than 300 Cameroonians travelled to China for various training programs, Currently there are about 1700 Cameroonians studying in China, making it the highest number of African students in China (Ndukong 2018).

Based on provisions of scholarships on the Chinese government scholarship website, students from Cameroon receives scholarships, not only from the Chinese government, but also from independent institutions and direct university scholarships in China. 
Table 1.scholarship categories

\begin{tabular}{|l|l|}
\hline No & Scholarship Category \\
\hline & Chinese government scholarships \\
& local government scholarships \\
& University scholarships \\
& Confucius institute scholarships \\
& Enterprise scholarships \\
& Other scholarships \\
\hline
\end{tabular}

Source: Authors illustration

Usually, some Cameroonian student travel to China on self sponsorship (i.e without scholarship) on getting to China, some are lucky to obtain a school scholarship after one year based on their academic performance and the school regulatory system. This also concurs with the finding in the study of (Ferdjani 2012) where low tuition and affordable cost of living are the major factors attracting self-funding African students to China. Different categories of Cameroonian students travel to China every year which include bachelors, masters and doctoral students (Nordtveit 2011; Omoruyi et al. 2017). However, the present study found that access to data, for instance, on the number of self-funding students, the number of returnees after training have proved abortive. Therefore, it is difficult to capture the number of trained returnees for a follow up assessment as reported in (Kirkpatrick 1975) model.

Moreover, studies have also related the experience of African students in China (Ishmail and yang 2003; Bodomo 2015; Li 2018) towards cultural constraints that might be affecting their academic life. Language barrier and other constraints as reported by a self-sponsored bachelor's degree Chemistry student Richard from Cameroon who withdrew from his school in China and returned to Cameroon after he felt he was not satisfied with what was been taught. In addition, lack of proper curriculum that aligns with the needs of enterprises outside China also raises some serious concerns about the quality of education they receive and the skills they possess as Chinese university graduates. Farell and Grant (2005)estimated that only 1.2 million of 15.7 million university graduates (or 7.6\%) have skills that are valued by international job markets. As such, the vast majority of students educated in Chinese universities lack adequate skills to compete internationally except for most local Chinese industries. This is evident in some research that shows that most African students (Ferdjani 2012; Bodomo 2015) tends to enroll in Chinese-language courses or engineering degrees. The Chinese language course enables them to integrate well with Chinese enterprises, while those who choose engineering course do so because they are taught in English (Victoria and Nathan 2017). findings of Ferdjani (2012) shows that African students are more inclined to Science (Engineering, Mathematics, Computer Science, Information Technology) and Economics (Financial accounting, Accounting, Finance, Business Administration, International Trade) that the other areas of studies. Major reasons are the content of the course and the reputation/ranking of the school.

\subsection{The University Cooperation Between Cameroon And China}

The higher education cooperation between China and Africa represents the earliest form of educational cooperation between the two parties. Introduced since the $1980 \mathrm{~s}$, it was aimed at assisting African countries to build and improve the curriculum systems in higher education studies, and cultivate scientific and technical talents. This period also were marked with donations of teaching facilities and scientific equipment to African countries by the Chinese government. A report from Compiling Group of China Africa Cooperation, (2005), stated that With the support and help from China, about 23 advanced laboratories in the fields of biology and microbiology, physics, material science, analytic chemistry, food preservation, horticulture, civil engineering and Chinese language teaching centers have been built in African universities as cited from (Niu 2013). further more, Nordtveit (2011) cited the 1993, university cooperation signed between University of Yaounde' I and the University of Zhejiang (ZJU) for student exchange and research cooperation in the field of sciences and microbiology as the earliest form of university cooperation between China and Cameroon. Niu, noted that the cooperation is still on till date but no more significant. The cooperation led to the equipping of the microbiology laboratory by china, sending of 10 Chinese teachers and the graduation of 10 Master degrees, 13 DEA [diplôme d'e'tudes approfondies, or "diploma of advanced studies"' (MPhil equivalent)], and five PhD students by 1997. Nevertheless, more impetus have been given to higher educational cooperation since the $3^{\text {rd }}$ and the $4^{\text {th }}$ FOCAC forum. In other to enhance exchange of research and ideas, promote higher education studies to boost scientific and technical talents cultivation, the 2009 FOCAC forum announced the 20+20 university cooperation between China and African countries. The final twenty Chinese universities selected for the $20+20$ project included several eminent institutions, such as Peking University, Jilin, East China Normal, Shanghai Normal, Hunan, and Beijing Language and Culture Universities. On the African side, most were in the top 100 African higher education institutions (HEIs); these included some of the continent's most prestigious universities, such as Pretoria, Stellenbosch, Makerere, Lagos, Dar es Salaam, Nairobi and Cairo (King 2014). in line with the 20+20 university cooperation, in 2017, the Cameroon embassy in China signed a memorandum of understanding (MOU) 
with Xingtai polytechnic college, Heibei province to grant scholarships to Cameroonian students in various disciplines. The MOU aims at providing training for 20 Cameroonian students each year in Diploma programme (the Cameroonian equivalent of Higher National Diploma, HND), With full scholarship(free tuition, accommodation, health insurance, books and a monthly stipend of 1,500 RMB (126,727 FCFA). The Students undertake a year's study of Chinese language in Cameroon before proceeding to China to read their courses for two years. Upon completion, they can enter university for two years to obtain a Bachelor's degree (Ndukong 2018). further aspect of training for Cameroonians is the Chinese language training which we shall discuss below.

\subsection{The Confucius Institute Training}

In December 1995, China and Cameroon agreed to cooperate and create the first chinese center. Then the center kick started in 1996 as a higher education cooperation between Zhejiang Normal University in China, and University of Yaounde' II in Cameroon. In November, 2007 the center was upgraded to Confucius institute under the supervision of the Chinese language governing center (Hanban). it became the first Confucius institute in Cameroon boasting 7 teaching centers and by 2011 a total of 6000 student registered in the institute (Dreher et al. 2017). Confucius Institutes offer scholarships and Chinese language teaching resources. They organize Chinese Proficiency Tests and certify Chinese language teachers, provide information and consultancy services on Chinese education, culture, and organize language and cultural exchanges between China and other countries as stated by Xia Jianhui, Hanban deputy director general (Ndukong 2017b). The establishment of Cameroon Confucius institute(hence forth CI) is based on agreement by both the University Yaoundé II, in Cameroon and Zhejiang Normal University in China to support Chinese studies in Cameroon, they jointly work on the, development, planning, advertisement and promotion of Confucius Institute under the supervision of the Office of Chinese Language International Council (Hanban). Funding is also a duel responsibility by both parties: the University of Yaoundé II, through international relations institute of Cameroon (IRIC) for Cameroon and HANBAN (Confucius Institute Headquarters affiliated with the Chinese Ministry of Education) for China. Apart from this direct funding by both parties, there are self-generated funds that the Confucius Institute gets from tuition fees and other channels. Since the establishment of CI in Cameroon, the institute have grown from less than 200 students at inception to about 1000 steady growth of new students annually (Mbom 2015). In 2017, the CI celebrated their $10^{\text {th }}$ anniversary and by the end of 2018, the institute boasts of over 10,000 registration from students. According to Hanban news, In 2017, the institute has set up 26 teaching centers with over 40 teachers and volunteers teaching Chinese language. In 2016, the CI center at the university of Maroua became the first in west Africa to graduate teachers in chinese language education. So far as reported by Ndukong (2017c), 200 have graduated from the programme whose Head of Department trained in Zhejiang Normal University. He further noted that Zhejiang Normal University has offered to train Cameroonian civil engineers for free so that they can return home and boost the local construction industry. In line with the above statement, it could be stated that, as the interest for Chinese language is growing, there's gradual shift from an ideologybased interest in Chinese language and civilization towards economic interest. Nevertheless, the aim of the paper is not to reiterate promises made (both fulfilled and unfulfilled) within the Sino-Cameroon education cooperation, but to critically examine it impact on Cameroonians, as they are on the receiving end of the win-win cooperation. The above statement concurs with the observations of (king 2010). ${ }^{1}$ To this end, on the side of the Confucius institute training in Cameroon, it is no doubt that China is training and graduating home grown(Cameroonians) teachers for Chinese language teaching, however only a few number might be gainfully employed. As Hanban continues to send more native (Chinese) teachers and volunteers to assist in Chinese teaching of which usually are not Chinese language trained teacher but are opportuned to be native speakers. Again, as king (2010) stated, Even if there has not been any formal evaluation of short-term training over the past 3 years, the Chinese government and its African partners must have judged it very positively. There are records of trained 200 local Chinese language teachers (Ndukong 2017c), however there are no formal records of follow up assessment on this teachers. It is also difficult to obtain records on the number of trained teachers per annum. As such, the limited data have made it difficult to assess China's contribution in this area towards providing employment opportunity for the locally trained Chinese teachers.

3.5 Development Of Education and Training Projects In Cameroon.

China as stated earlier to be seen as a partner than as an Aid donor. Like other donors in Cameroon, china have contributed to school construction and education material assistance in Cameroon, however, they are still behind Japan in the area of primary school construction in Cameroon (Omoruyi et al. 2017; Nordtveit 2011). In line with the 2006 FOCAC pledge to build 150 primary rural schools in Africa between 2006 and 2012, and the

\footnotetext{
${ }^{1}$ While the precise mix of the training courses is negotiated annually at the country level, the offer of such training to Kenya as to other African countries is a key element in the overall FOCAC aid package of 15,000 trainees in the current 3-year period. Numbers for any country are set in Beijing, and there is no complementarity expected of Kenya, in the sense of Chinese coming to short term courses hosted by Kenya(see king 2010: p491).
} 
Chinese Premier WenJiaobao's announcement in 2010 for construction of 200 elementary schools in developing countries by the Chinese government from 2010 to 2015, China by 2009 completed the construction of three primary schools in Cameroon. Also in 2017, China completed the construction and equipped Yabassi professional agricultural high school which was described as a gift from china to Cameroon (Ndukong 2017a). In addition, the production of 500,000 laptops for Cameroonian university students by China's Sichuan Telecommunications Construction Engineering Co. Ltd funded by the China exim bank which was described as part of the e-National Higher Education Network project being put in place by government of Cameroon (Atabong 2018). However, Omoruyi et al. (2017), holds the same view about Chinese companies and skill deficit where he stated that Contrary to the Japan, the largest bilateral donor in primary school construction in Cameroon who generally makes use of a local subcontractor doing construction, the Chinese is using technicians from China; materials are brought from China or purchased in Cameroon. Again with increase opportunity for training of Cameroonians under the FOCAC framework, as pledges increases with each successive tri-annual summit, a significant impact is yet to be made toward transferring the technical know-how that will help Cameroon Innovate independently. Furthermore, in areas of skill transfer through Chinese enterprises, Studies have shown that Chinese loans for infrastructural development goes from the Chinese banks to state owned companies (Dollar 2016; Brautigam \& Hwang 2016) Then the contracted companies usually make use of workers who are tied to contracted project rather than Chinese workers who are under labour service arrangements as shown in fig2 below. This is consistent with the notion raised by Dollar (2016) that Chinese construction companies have used the tied support from bilateral projects (i.e., China Exim Bank's lending money to African countries for infrastructure projects that have to be carried out by Chinese firms) to become a competitive force on the Africa continent.

\section{Number of Chinese Workers in Africa by End of Year 2015}

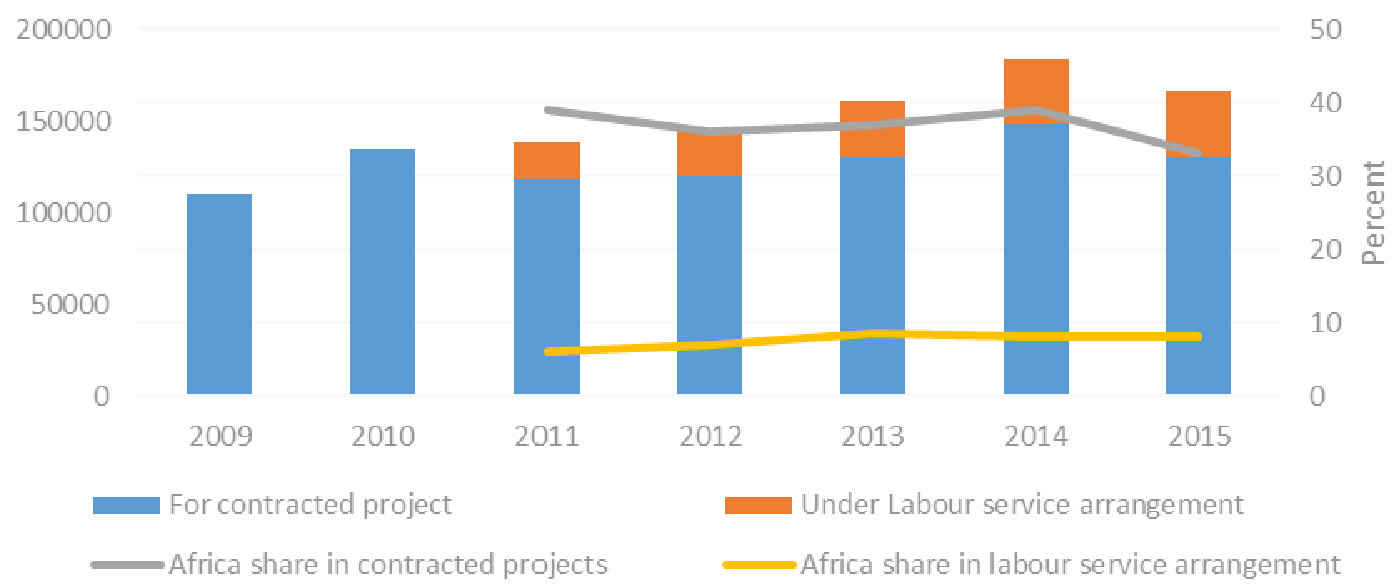

Fig 2. Source: ( Brautigam at al. 2017).

He further noted that the greater number workers who are tied to the contracted project helps to facilitate faster construction of infrastructure, provide missing skills, and useful connections to the second-largest economy in the world. However, the workers who are tied to the contracted project do not transfer skills to the locals as their target is to complete the project with the shortest period of time. While the Chinese workers who are under labour service arrangements are more skilled and are capable of transferring the required technical know-hows, they are less likely used in delivering this hard infrastructural projects. This also concurs with the findings of Brautigam at al. (2017) that the share of Chinese workers in Africa who go abroad through labour service arrangements is very small, at about 5-6\% in 2011-2015. As such, the challenges of going back to China to source for funds and skills needed to maintain this infrastructures is always inevitable. Although there seems to be remedy to this issues for instance, - Ethiopia-Djibouti rail model, which have 600 Chinese employees and about 3000 local employees. The Chinese company will manage the rail for 6 years and train local employees within these period (People's daily overseas news media 2019). However, without strong internal policy framework, Cameroon may not be able to achieve the goal of acquiring the skill necessary to innovate independently as no country is willing to trade its comparative advantage. Nevertheless, China's efforts in assisting Cameroonian improve access to education by offering free schools building and educational material are welcomed and considered to be the positive and beneficial role of China's aid towards the improving the education development in Cameroon when compared with the traditional donors. 


\section{Improving The Education And Skill Development Through Pragmatic Engagements With China.}

Education and skills development are important for Africa to close the gap that have been created by lack of local skill which prevents Africa from fully unlocking private investments for key infrastructure development. (UNDP 2016). Clearly stated in the African Union's 'Agenda 2063, the Africa we want,' is need to catalyse education and skills revolution. This includes; building technical and vocational training centers in Africa; developing an African Accreditation Agency to monitor and develop African education standards; strengthening the Pan African University; actively promote science, technology, research and innovation--to build knowledge, human resources, capabilities and skills for the African century. Africa's education systems and skills development can improve through sharing of developmental objectives and experiences from developed and emerging economies through exchanges of knowledge, skills, resources and technical know-how, required to build human, institutional and systemic capacities, capable of self-sustaining (UNDP 2016). As such, opportunities presented by cooperation from emerging economies especially within the south-south cooperation like Brazil, India, China, and the rest will be beneficial to tackle the bottlenecks towards education and skills development.

African countries face challenges related to shortages of a qualified labour force and institutional capacity (UNDP 2016). Despite the substantial growth of many African economies over the last decades with an estimated real output growth of $4.1 \%$ in 2019 (AfDB 2018), several African nations are still struggling to transition to higher value-added economic activities due to the significant gap between demand and supply of skills required for the labor market (Ehizuelen 2018). China through the FOCAC framework seeks to strengthen ties with African countries by adopting Pan -African method of responding to the pressing need in different African countries. China is not the only emerging economy supporting Africa's education and skill development, Brazil and India also contributes to education and skills development in Africa through the private-sector firms which provides scholarships, corporate social responsibility programs, business strategies and training (Vazquez And Carrillo 2014; UNESCO 2014). Nevertheless, China is viewed as a major player towards human resource development in Africa(King 2009; Dollar 2016). China's pledges and contributions towards the improvement in the area of education and skill development in Africa is viewed as a positive steps towards Africa's quest to develop and diversify its economies. The overall engagement in the area of education and skill development through - long term and short term scholarship training, Confucius institute training, higher education cooperation, educational projects etc. depicts China's soft power diplomacy towards Africa (Sullivan 1994; king 2009).

China's Support To Short Term And Long Term Training Of Africans In China is viewed as a means of building capacity and skill transfer. Capacity building among local technicians along with supervisory expertise and skills, will be integral for the long-term sustainability of large infrastructure projects and innovative training in area of education in the continent. As such, Sino-Cameroonian education cooperation should be geared towards innovative education and adequate skill that can enable Cameroon innovate independently. Studies have shown that countries can benefit and add value through their cooperation with other countries if they have strong internal policy and implementation strategies (Dollar 2016; Omoruyi et al. 2017). Institutional capacity is vital for recipient countries to properly appropriate any opportunity presented within their cooperation. Dollar (2016) gave a clear view of institutional influence where he stated that, in a bid to bridge the skill gap in China, after the beginning of reforms 1978, Chinese officials restricted visas for foreign workers. This system put pressure on foreign investors to train local Chinese as fast as possible to fill skilled positions. China's development paradigm could serve as a model for Cameroon; however, it must be with Cameroonian characteristics, due to different political and cultural ideologies held by the two countries. The FOCAC pledges in the area of education and training, especially the recent which announced the increase of scholarship to 50000 in 2018 and training for African students presents opportunity for Cameroonian leaders to appropriate for their citizens. A report published by the Ministry Of Education Of The People's Republic Of China shows that, China is also putting up reforms to upgrade most of its universities to meet the world standards and has established joint education programs with Europe and American universities (MOE 2018). Through the different initiatives in the area of education and skill development for instance the - 20+20 University cooperation, the Confucius institute higher education cooperation which is expanding from language based to encompass other aspect of economic and cultural engagements, China has shown its readiness in assisting African countries towards improving the education sector. Also in 2017, Zhejiang normal university opened it first innovation center with the aim of meeting the requirement for practical education and skill transfer. The center aims also at fostering cooperation between the university and the Chinese enterprises who offer jobs and internship opportunities for foreign student in the university. The partnership between the University of Yaoundé II and Zhejiang normal University presents a more privilege for Cameroonian students to tap from the opportunities the cooperation has presented. Also, Chinese companies like Huawei, ZTE and few SOEs have realized the importance of skills transfer in the development of local economy, as a good strategy to open African market and enhance their businesses and for the structural transformation of Africa (Ehizuelen 2018). As such, pragmatic engagements such as formal 
evaluation and follow up processes on the overall cooperation in education, backed by strong internal policy regulation and implementation would be required for Cameroonian people to overly appreciate China's pragmatic role in Sino- Cameroonian education cooperation.

\section{Conclusion}

The objective of this study was to shed light on impact the of China education cooperation. It is important to note that educational cooperation within China- African relation have come a long way since the 50s and now in the $21^{\text {st }}$ century boosted by the FOCAC framework. The FOCAC framework have made China an important donor towards educational development in Africa. However, China refuses to be seen as a donor but rather as a partner towards Africa and prefer not to bare open options for the allocations and use of educational handouts, especially in the area of human resource development. The absence of formal evaluations on assistance towards education and skill development also depicts how China views educational cooperation with Africa, whether as a particular sector or an integral part of developmental assistance within the cooperation. China is playing active role towards supporting Africa's educational development and skill transfer as evident in the pledges that have been made so far, however, it impact can only be appreciate when African countries begins to do things for themselves without totally dependent on external help. To this end, Cameroon should actively engage China to leverage on addressing the skill gap through innovative education. Although there have been records of meaningful progresses achieved in boosting education and skills development in China- Cameroonian educational cooperation, much are yet to be done especially in the areas pointed out in this paper. Aligning the curriculum with the needs of the labour market, encouraging firms, enterprises and multilateral companies within the country to invest in training and skill acquisition programs and ensuring that skills are well utilized within the right sector and designated jobs should be at the fore front of Cameroon's strategy towards improving the educational standard, bridging the skill gap and achieving the 2035 agenda of making the country a middle economy. The paper have discussed some of the modalities within China- Cameroonian higher education partnership , the 20+20 university partnership as well as the Confucius institutes initiatives. Sino - Cameroonian education cooperation should be reinforced in teaching, research, and management to support human resources need in Cameroon as local economies develop. More,so infrastructural development such as Joint research laboratories should be established in Cameroon to encourage research in the areas of human endeavors and also creating opportunities for student exchange at all levels, to build mutual consensus and confidence. Finally, One thing China have always clearly stated is its policy of noninterference, as such Cameroon should be responsible for identifying and focus on what they want and can learn from China. In that we talk about strengthening their internal policy framework that can help them negotiate properly and engage China on a win-win platform.

\section{Acknowledgment}

We express our profound gratitude to God Almighty for the abundant blessings and favors throughout the research work. Secondly, we thanks the Zhejiang Normal University for the nurture so far in our academic pursuit.

\section{References}

African Union, Agenda 2063: The Africa We Want. (2014), Available at http://agenda2063.au.int/en/sites/default/files/agenda2063 popular version 05092014 EN.pdf.

African Development Bank. (AfDB). (2018), African economic outlook. Available at: https://www.afdb.org/fileadmin/.

Atabong, B.A. (2018), How China is restructuring Cameroon's burgeoning digital economy sector. Available at: http://africachinareporting.co.za/2018/07/how-china-is-restructuring-cameroons-burgeoning-digitaleconomy-sector/.

Baker, M., Creedy, J. \& Johnson, D. (1996), Financing and Effects of Internationalization in Higher Education: An Australian Country Study.

Bodomo, A. (2015), African Students in China. Available at: https://www.researchgate.net/publication/266296514.

Bogdan, R. C. \& Biklen, S. K. (2003), Qualitative research for education: An introduction to theories and methods (4th ed.). New York, N.Y.: Pearson.

Brautigam, D. (2009), The Dragon's Gift: The Real Story of China in Africa. Oxford: Oxford University press.

Brautigam, Deborah. \& Jyhjong,Hwang. (2016), "Eastern Promises: New Data on Chinese Loans in Africa, 2000 to 2014," China Africa Research Initiative Working Paper No. 4, Johns Hopkins University, School of Advanced International Studies.

Brautigam, D., Diao X., McMillan, M. \& Silver, J. (2017), Chinese Investment in Africa: How Much Do We Know? PEDL Synthesis Series. No. 2.

Cabestan, Jean-Pierre. (2015), China-Cameroon relations: Fortunes and limits of an old political complicity. 
South African Journal of International Affairs, DOI: 10.1080/10220461.2015.1014930.

Changsha Municipal Government. (2014), Chinese Government Scholarship. Available at:http://en.changsha.gov.cn/study/Scholarships/201407/t20140716_612155.html?yundunkey=1c4902be473 f95780c96f7666c1c9eaa91418250529 147371045.

Cameroon-China to reinforce ties. (2017), Available at: https://www.prc.cm/en/news/audiences/2119-cameroonchina-to-reinforce-ties-in-2017.

China Education Center. (2019), Available at: https://www.chinaeducenter.com/en/cedu.php

China's higher education. (2016) "China to overtake UK as a study abroad destination" Available at: http://www.chinadaily.com.cn/china/2016-09/17/content 26811371.htm.

Clinton, H. R. (2011), “Interview on Africa 360”, U.S Department of State, Diplomacy in Action. Available at; http://www.state.gov/secretary/rm/2011/06/165941.htm

CSCUK. (2014), A Study of Research Methodology Used in Evaluations of International Scholarship Schemes for Higher Education. In Makundi, H., Huib H., Patrick D., Benedict M. \& Lettice R. (2017), Training abroad and technological capacity building: Analysing the role of Chinese training and scholarship programme for Tanzanians. International Journal of Educational Development 57: 11-20.

Cuthbert, D., Smith, W. \& Boey, J. (2008), What do we really know about the outcomes of Australian international education? a critical review and prospectus for future research. J. Stud. Int. Educ. http://dx.doi.org/10.1177/1028315307308134.

Dollar, D. (2016), China's Engagement With Africa-From Natural Resources To Human Resources.John L. Thornton China Center Monograph Series.. Brooking institution.

Dong, L. \& Chapman, D. W. (2008), The Chinese Government Scholarship Program: An Effective from of Foreign Assistance? International Review of Education, 54 (2), 155-173.

Dreher, A., Fuchs, A., Parks, B.C., Strange, A. M. \& Tierney, M. J. (2017), Aid, China, and Growth: Evidence from a New Global Development Finance Dataset. AidData Working Paper \#46. Williamsburg, VA: AidData.

Edeh, E.C. \& Wang,H. (2018), China-Nigeria Cooperation In Education And Training: A Comparative Analysis. North American Academic Research. 1(7)144-165.

Ehizuelen, M. M. O. (2018), Education And Skills Development In China-Africa Cooperation. Higher Education Press and Springer-Verlag GmbH Germany. https://doi.org/10.1007/s11516-018-0030-0.

Fantu, C. \& Cyril, O. (2010), "The Rise of China and India in Africa: Challenges, Opportunities and Critical Interventions", The Nordic Africa Institute.

Farell, D \& Grant, A. (2005), Addressing China's looming talent shortage". Available at: http://www.mckinsey.com/global-themes/china/addressing-chinas-looming-talent-shortage.McKinsey \& Company.

Ferdjani, H. (2012), African students in China An exploration of increasing numbers and their motivations in Beijing.Centre for Chinese Studies, Stellenbosch University.

Freschi, L. (2010), "China In Africa Myths And Realities", AIDWATCH. Available at. http://aidwatchers.com/2010/02/china-in-africa-myths-and-realities/.

FOCAC. (2000), "Beijing declaration of the forum on China-Africa cooperation". Available at: www.focac.org/eng/ltda/dyjbzjhy/DOC12009/.

FOCAC. (2005), Sino-African Education Minister Forum issues Beijing Declaration. Available at: http://www.focac.org/eng/zt/zfjybzlt/t223750. Htm.

FOCAC. (2006), Forum on China Africa Cooperation Beijing Action Plan (2007-2009). available at: http://mz2.mofcom.gov.cn/article/bilateralvisits/200611/20061103820760.shtml

FOCAC. (2009), Forum on Africa-China Cooperation Sharm El-Sheikh Action Plan. Available at: http://www.focac.org/eng/ dsjbzjhy/hywj/t626387.htm.

FOCAC. (2012), The Fifth Ministerial Conference Of The Forum On China-Africa Cooperation Beijing Action Plan (2013-2015). available at: http://www.focac.org/eng/ltda/dwjbzjjhys/hywj/t954620.htm.

FOCAC. (2015), Forum on China-Africa Co-operation 'Johannesburg Declaration and Action Plan'. Available at: http://in.china-embassy.org/eng/zgxw/t1323159.htm.

FOCAC. (2018), china-promises-60-bn-aid-to-africa-as-summit-opens.available at: https://www.google.com/amp/www.africanews.com/amp/2018/09/03/

Gillespie, S. (2006), "Voices of African Students in China" International Christian University, Japan. Available at: http://www.cctr.ust.hk/china-africa/programme.pdf

He, W. (2007), "Educational exchange and cooperation between China and Africa - development phases and challenges". West Asia and Africa. No. 3, pp. 13-18.

Hu, Jinxin. (2013), China-Africa Hand in Hand, Good News for Global--sidelights of Sino-Africa Investment Summit [Online]. Available at: http://paper.people.com.cn/rmrbhwb/html/2013-06/01/content 1248274.htm. Ismail, H.H. \& Yang Z.L. (2003), Cultural and gender differences in perceiving stressors: a cross-cultural 
investigation of African and Western students in Chinese colleges. Available at https://doi.org/10.1002/smi.978.

Jian, J. (2015), China-Africa humanistic education co-operation: a road toward cultural diversity. African EastAsian affairs. Centre for Chinese Studies, Stellenbosch University.3(4): 30-53.

Kaufman, R., Keller, J. \& Watkins, R. (1996), What works and what doesn't: evaluation beyond Kirkpatrick. Perform. Instruction 35 (2), 8-12.

Ketema, M. D. \& Hong, Zhu. (2009), Towards a Sustainable Counterbalanced Development Educational Cooperation between China and African Countries. Sino-African Education Cooperation References, 1-22.

King, K. (2018), China will continue to back Confucius Institutes in Africa. Available at: http://www.chinadaily.com.cn/a/201808/24/WS5b835c0aa310add14f387e76.html

King, K. (2009), China's cooperation in education and training with Kenya: a comparative analysis.UKFIET Conference on International Education and Development, 15-17 September 2009, Oxford.

King, K. (2010), China's Cooperation in Education and Training with Kenya: A different model?. International Journal of Educational Development. 30(5), 488-496.

King, K. (2013), China's Aid and Soft Power in Africa: The Case of Education and Training. JSTOR.

King, K. (2014), "China's Higher Education Engagement with Africa: A different Partnership and Cooperation Model?" in Education, Learning, Training : Critical Issues for Development, International Development Policy series No.5, Geneva: Graduate Institute Publications, Boston: Brill-Nijhoff, pp. 151-173.

Kirkpatrick, D.L. (1975), Evaluating Training Programs. In Makundi, H., Huib H., Patrick D., Benedict M. \& Lettice R. (2017), Training abroad and technological capacity building: Analysing the role of Chinese training and scholarship programme for Tanzanians. International Journal of Educational Development 57 : 11-20.

Kragelund, P. (2014), Chinese Soft Power and Higher Education in Africa: The Confucius Institute at the University of Zambia. EADI Conference Paper.Available at: https://www.conftool.com/gc2014/index.php/GC2014-Kragelund-249.pdf?page=downloadpaper\&filename $=\mathrm{GC} 2014-$ Kragelund-249.pdf\&form_id=249\&form_dex=2\&form_version=final.

Li, B. (2006), "Effectiveness and difficulties of Sino-Africa educational collaboration' paper to China-Africa Links Workshop, 11-12 November, Hong Kong University of Science and Technology, Hong Kong.

Li, A. (2007), "China and Africa: policy and challenges", China Security. 3(3), pp. 69-93.

Li, A. S. (2018), African students in China: Research, reality, and reflection. African Studies Quarterly, 17(4), $5-44$.

Lum, Thomas., Hannah, Fischer., J. Gomez-Granger. \& A. Leland. (2009), "China's foreign aid activities in Africa,Latin America, and Southeast Asia," Congressional Research Services.

Makundi, H., Huib H., Patrick D., Benedict M. \& Lettice R. (2017), Training abroad and technological capacity building: Analysing the role of Chinese training and scholarship programme for Tanzanians. International Journal of Educational Development 57: 11-20.

Mbom, Sixtus. (2015), Confucius Says "Cameroonians show growing interest in learning Chinese language and culture”. Available at: http://www.chinafrica.cn/Cover_Story/txt/2015-07/06/content_694714.htm.

Ndukong, K. H. (2017b), Cameroon: Chinese Language - Confucius Institute to Train More Cameroonian Instructors. Available at: http://za.china-embassy.org/eng/zfgxss/t1495433.htm.2017/08/30.

Ndukong, K. H. (2017a), Chinese-built professional agriculture high school goes operational in Cameroon. Available at: http://en.people.cn/n3/2017/0818/c90000-9257351.html

Ndukong, K. H. (2017c), Cameroon: Chinese Language Training - Confucius Institute Cameroon Prepares 10th Anniversary. Available at: https://allafrica.com/stories/201710260244.html.

Ndukong, K. H. (2018), Cameroon: Apogee of Educational Collaboration.Available at: https://allafrica.com/stories/201803220673.html.

Niu, Changsong. (2013), "China's educational cooperation with Africa: toward new strategic partnerships". Asian Education and Development Studies. 3 (1):31-45, https://doi.org/10.1108/ AEDS-09-2013-0057.

Nordtveit, B. H. (2009), Western and Chinese Development Discourses: Education, Growth, and Sustainability. International Journal of Educational Development. 29 (2), 157-165.

Nordtveit. B.H. (2011), An emerging donor in education and development: A case study of China in Cameroon. International Journal of Educational Development.31 (2011) 99-108.

Obamba, M. (2013), The Dragon's Deal: Sino-African Cooperation in Education.International Higher Education, $72,7-8$.

Omoruyi,M.M.E., Yao J.J., Abah B.A.S. \& Mvuh Z. (2017), China Enhancing Education Development in Africa: A Case Study of Cameroon. Research on Humanities and Social Sciences.7(15): 8-19.

Perna, L.W., Orosz, K., Gopaul, B., Jumakulov, Z., Ashirbekov, A. \& Kishkentayeva, M. (2014), Promoting human capital development a typology of international scholarship programs in higher education. Educ. Res. 43 (2), 63-73. http://dx.doi.org/10.3102/0013189X14521863. 
People's Daily Overseas New Media. (2019), Addis Ababa-Djibouti Railway, providing development momentum for Ethiopia, Djibouti. Available at: http://en.people.cn/n3/2019/0226/c90000-9549933.html.

People's Republic of China (PRC). (2006), China's African policy, available at: http://www.fmprc.gov.cn/eng/zxxx/t230615.htm.

Ryan, G. W. \& Bernard, H. R. (2002), Data management and analysis methods. In N. K. Denzin, \& Y. S. Lincoln (Eds.), Handbook of qualitative research (2nd ed., pp. 730-783). Thousand Oaks, C.A.: Sage Publishers.

Shao, K.. (2012), Blackboard Cooperation: China's Role in Educating Africa. Consultancy Africa Intelligence.Available at: http://www.consultancyafrica.com.

Sheehy, K. (2013), "Explore the World's Top Universities" available at: https://web.archive.org/web/20141024162032/http:/www.usnews.com/education/top-worlduniversities/articles/2013/10/08/explore-the-worlds-top-universities?page=2

Statistics of Foreign Students in China " People's Republic of China Ministry of Education April 14, 2016.

Sullivan, M.J. (1994), The 1988-89 Nanjing anti-African protests: racial nationalism or national racism? China Q. 138, 438-457. http://dx.doi.org/10.1017/ S0305741000035839.

Sun, Y. (2014), Africa In China's Foreign Policy. John L. Thornton China Center and the Africa Growth Initiative at Brookings.

Tamkin, P., Yarnall, J. \& Kerrin, M. (2002), Kirkpatrick and Beyond: A Review of Models of Training Evaluation. IES Report. ERIC available at: http://eric.ed.gov/?id= ED470777.

Tull, D. (2006), 'China's engagement in Africa: scope, significance and consequences', Journal of Modern African Studies, 44,3,459-479

UNDP. (2016), Advancing south-south cooperation in education and skills development: lessons from the field,One United Nations Plaza New York, NY 10017, USA Web site: www.undp.org/ssc.

UNESCO. (2014), 'BRICS, building education for the future. Priorities for national development and international cooperation.’ Paris, UNESCO.

UNESCO. (2015), Education for All 2000-2015: Achievements and Challenges. UNESCO, Paris.

Varrall, M. (2015), "Domestic Actors and Agendas in Chinese Aid Policy," The Pacific Review 29(1): 1-24.

Vazquez, K.C. \& Carrillo, S. (2014), 'Sustaining the Benefits of Brazilian Direct Investment in Sub-Saharan Africa: Skills and Capacity Development.' Rio de Janeiro: CEBRI.

Victoria, B. \& Nathan, M. (2017), China tops US and UK as destination for anglophone African students. Available at https://theconversation.com/china-tops-us-and-uk-as-destination-for-anglophone-africanstudents-78967.

Vision (2035). (2009), Republic of Cameroon ministry of the economy, planning and regional development, secretariat-general, forecast and strategic planning division Cameroon vision 2035 working paper.

Woodfifield, S. (2009), Trends in International Student Mobility: A Comparison of National and Institutional Policy Responses in Denmark, Germany, Sweden and The Netherlands. Available at: http://eprints.kingston.ac.uk/19772/1/Woodfifield2009-

Trends_in_International_Student_Mobility_A_Comparison_of_National_and_Institutional_Policy_Respo nses_in_D.pdf.

World population review. (2019), Available at: http://worldpopulationreview.com/countries/cameroonpopulation/.

Yuan, T. (2013), The rising China model of educational cooperation with Africa. In: Majhanovich, S., Geo-JaJa, M.A. (Eds.), Economics, Aid and Education. Sense Publishers, Rotterdam, pp. 183-198. Available at: http://link.springer.com/ 10.1007/978-94-6209-365-2_12.

ZHENG, Yu. (2016), China's Aid and Investment in Africa:A Viable Solution to International Development?yzheng@fudan.edu.cn. Fudan University. 